Check for updates

Cite this: RSC Adv., 2018, 8, 15036

\title{
Yunnanterpene $G$, a spiro-triterpene from the roots of Cimicifuga foetida, downregulates the expression of CD147 and MMPs in PMA differentiated THP-1 cells $\uparrow$
}

\author{
Ni-Hong Lu, ${ }^{a}$ Zi-Wei Zhang, ${ }^{b}$ Rui-Wei Guo, ${ }^{b}$ Li-Xia Yang, (D) *b Ya-Xian Song, ${ }^{a}$ \\ Jin-Shan $\mathrm{Ye}^{\mathrm{b}}$ and Yan-Kun Shi ${ }^{\mathrm{b}}$
}

A new cycloartane triterpene, yunnanterpene G (1), containing an oxaspiro[5.4]decane moiety, was purified from the roots of Cimicifuga foetida. The new structure was determined from spectroscopic data and the $X-$ ray diffraction method. Biological evaluations revealed that compound 1 significantly inhibited the mRNA expression of the atherosclerosis-related adhesion molecule CD147 (extracellular matrix metalloproteinase inducer, EMMPRIN), and proteolytic enzymes matrix metalloproteinase 2 (MMP-2), MMP-9 and MMP-14, in a dose-dependent manner in phorbol-12-myristate-13-acetate-induced human monocytic THP-1 cells by quantitative real-time PCR method. At the same time, the migration ability of the induced THP-1 cells was potently inhibited. Furthermore, western blot experiments showed that compound 1 at $25 \mu \mathrm{M}$ strongly suppressed phosphorylation of NF- KB p65 and p38 MAPK in the differentiated THP-1 cells.

Received 4th March 2018 Accepted 2nd April 2018

DOI: $10.1039 / c 8 r a 01895 b$

rsc.li/rsc-advances

Cimicifuga spp. (now included in the genus of Actaea), such

\section{Introduction}

Atherosclerosis is a type of chronic inflammatory disease. ${ }^{\mathbf{1 - 3}}$ Thus, proper regulation of the key inflammatory factors involved in this disease is crucial for therapeutic strategies. CD147, extracellular matrix metalloproteinase inducer (EMMPRIN) or basigin, is a member of the immunoglobulin super family. ${ }^{4}$ Ample evidence has highlighted the potential effect of CD147 in the pathological process of atherosclerosis. ${ }^{\mathbf{1 , 5 - 1 0}}$ Especially, it has been proven that overexpressed CD147 in activated macrophages stimulated production of several matrix metalloproteinases (MMPs), including MMP-1, MMP-2, MMP-9, and MMP-14, in advanced atherosclerotic plaque, which is critical for plaque rupture and myocardial infarction. ${ }^{\mathbf{1 1 - 1 4}}$ Moreover, anti-atherogenic drugs, such as fluvastatin, besides LDL (low-density lipoprotein) reducing effect, decreasing the MMPs and EMMPRIN levels also contribute to their clinical outcomes. ${ }^{15-17}$ Thus, substances that suppress EMMPRIN and MMP expression may be potential candidates for ameliorating the development of atherosclerosis.

${ }^{a}$ Department of Postgraduate, Kunming Medical University, Yunnan, 650500, P. R. China

${ }^{b}$ Department of Cardiology, Kunming General Hospital of Chengdu Military Area, Yunnan, 650032, P. R. China.E-mail: doctorlxyang@126.com

$\dagger$ Electronic supplementary information (ESI) available: 1D and 2D NMR spectra, HRESIMS, UV, IR, and OR spectra of new compound 1. CCDC 1813083. For ESI and crystallographic data in CIF or other electronic format see DOI: 10.1039/c8ra01895b as $C$. racemosa, C. foetida, C. dahurica, C. heracleifolia, $C$. simplex, and C. japonica, are famous herb medicines in Europe, the United States, and East Asia. ${ }^{18-20}$ 9,19-Cycloartane triterpenes (CTs) are the main active chemical profile of Cimicifuga genus ${ }^{\mathbf{1 8 - 2 0}}$ and these CTs show diverse activities, such as cytotoxicity, $^{21,22}$ anti-angiogenic, ${ }^{23}$ anti-inflammatory, ${ }^{24,25}$ neuroprotective, ${ }^{26}$ soluble epoxide hydrolase inhibitory, ${ }^{27}$ anti-antiosteoporotic, ${ }^{28}$ anti-AIDS, ${ }^{29}$ and anti-Alzheimer ${ }^{30}$ activities. However, knowledge of the regulation of EMMPRIN and MMPs by CTs from Cimicifuga spp. is still unknown. In the present study, a spiro-triterpene, yunnanterpene G (1), was isolated from the roots of $C$. foetida (Fig. 1). Although containing the same 16,23:23,26-diepoxy moiety, the spiro-atom C-23 in 1 was assigned as " $R$ " with the help of X-ray crystallography, rather than " $S$ " in the analogues yunnanterpene A-F. ${ }^{20}$ Significantly, quantitative real-time PCR (q-PCR) experiments showed that compound 1 noticeably suppressed the mRNA expression of CD147, and MMP-2, MMP-9 and MMP-14, in a dose-dependent manner (10 to $50 \mu \mathrm{M}$ ) in phorbol-12-myristate-13-acetate (PMA)induced THP-1 cells (PMA differentiated THP-1 cell line is a representative macrophage model, in vitro ${ }^{31}$ ). Consequently, motility of the differentiated THP-1 cells was potently inhibited by 1 at the same concentration range. Furthermore, 1 markedly reduced phosphorylation of NF- $\mathrm{NB}$ p65 and p38 MAPK at a concentration of $25 \mu \mathrm{M}$. Described herein are the isolation, structure elucidation, and biological activities of compound $\mathbf{1}$. 


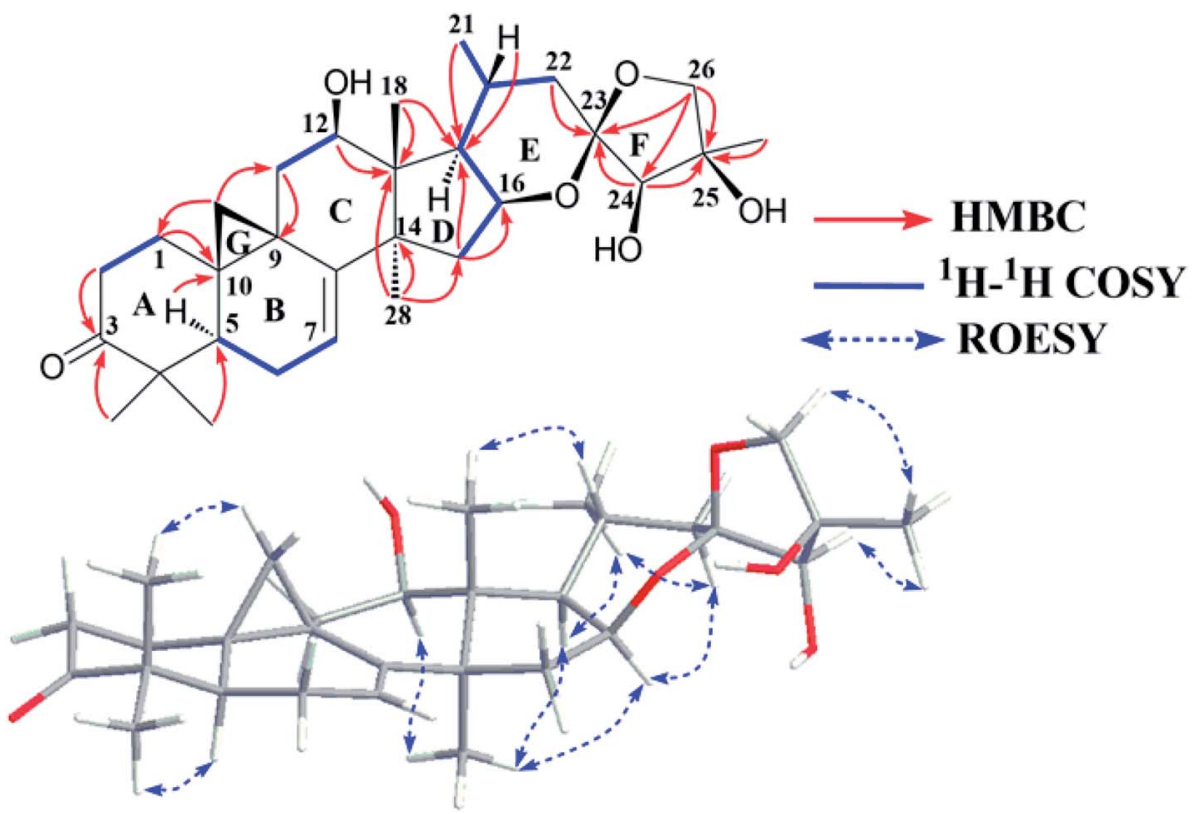

Fig. 1 Structure and major $\mathrm{HMBC},{ }^{1} \mathrm{H}-{ }^{1} \mathrm{H}$ COSY, and ROESY correlations of compound 1.

\section{Results and discussion}

\subsection{Structural elucidation of yunnanterpene $\mathbf{G}$}

Yunnanterpene $\mathrm{G}(\mathbf{1})$, colorless crystals, has the molecular formula $\mathrm{C}_{30} \mathrm{H}_{44} \mathrm{O}_{6}$ as determined by HRESIMS at $m / z 523.3029$ $[\mathrm{M}+\mathrm{Na}]^{+}$(calcd 523.3036), consistent with 9 sites of unsaturation. The IR spectrum showed absorptions ascribed to $\mathrm{OH}$ (3411 $\left.\mathrm{cm}^{-1}\right)$, carbonyl $\left(1705 \mathrm{~cm}^{-1}\right)$, and olefinic $\left(1631 \mathrm{~cm}^{-1}\right)$ groups. In the ${ }^{1} \mathrm{H}$ NMR spectrum (Table 1), downfield shifted cyclopropane methylene signals at $\delta_{\mathrm{H}} 0.86$ and 1.29 (each $1 \mathrm{H}$, brs), an olefinic proton resonance at $\delta_{\mathrm{H}} 5.17(\mathrm{dd}, J=6.1,2.6 \mathrm{~Hz}$ ), a secondary methyl signal at $\delta_{\mathrm{H}} 1.47(\mathrm{~d}, J=6.6 \mathrm{~Hz})$ and signals of five tertiary methyl groups at $\delta_{\mathrm{H}}$ 1.01-1.91 were observed. In addition, the ${ }^{13} \mathrm{C}$ NMR (Table 1 ) and HMQC spectra revealed the existence of a carbonyl group at $\delta_{\mathrm{C}} 214.8(\mathrm{C}-3, \mathrm{~s})$, a ketal carbon at $106.6(\mathrm{C}-23, \mathrm{~s})$ and five oxygenated carbon atoms at $\delta_{\mathrm{C}} 71.7(\mathrm{C}-$ 12, d), 75.5 (C-16, d), 85.8 (C-24, d), 77.8 (C-25, s), and 78.1 (C-26, $\mathrm{t})$. The aforementioned data suggested that 1 was a highly oxygenated CT containing a six-ring skeleton.

Study of the ${ }^{1} \mathrm{H}-{ }^{1} \mathrm{H}$ COSY (Fig. 1) and HSQC spectra of 1 revealed the existence of partial structures $\mathrm{C}-1 / \mathrm{C}-2\left(-\mathrm{CH}_{2} \mathrm{CH}_{2}-\right)$, C-5/C-6/C-7 (- $\left.\mathrm{CHCH}_{2} \mathrm{CH}-\right)$, C-11/C-12 (- $\left.\mathrm{CH}_{2} \mathrm{CH}-\right)$ and a pair of geminal signals for $\mathrm{CH}_{2}-19$ at $\delta_{\mathrm{H}} 0.86$ and 1.29 (each $1 \mathrm{H}$, brs), consistent with typical rings A, B, C, and G of CTs with a carbonyl group at C-3, a hydroxy group at C-12 and a pair of double bonds at C-7 and C-8. ${ }^{21-23}$ The HMBC correlations of $\mathrm{H}-2$ $\left(\delta_{\mathrm{H}} 2.70\right.$ and 2.24$)$ and $\mathrm{Me}-29\left(\delta_{\mathrm{H}} 1.01\right)$ to the carbonyl carbon at $\delta_{\mathrm{C}} 214.8(\mathrm{C}-3)$, and $\mathrm{H}-11 \quad\left(\delta_{\mathrm{H}} 2.82\right.$ and 1.49$)$ to the

Table 1 The NMR data of compound 1 ( $\delta$ in ppm)

\begin{tabular}{|c|c|c|c|c|c|}
\hline Position & ${ }^{1} \mathrm{H}^{b}$ & ${ }^{13} \mathrm{C}^{c}$ & Position & ${ }^{1} \mathrm{H}^{b}$ & ${ }^{13} \mathrm{C}^{c}$ \\
\hline 1 & $1.80 \mathrm{~m}, 1.51$ brd (6.5) & $31.8 \mathrm{t}$ & 16 & 4.84 dd $(14.0,7.4)$ & $75.5 \mathrm{~d}$ \\
\hline 2 & $2.70 \mathrm{td}(13.9,6.3), 2.24 \operatorname{brd}(11.7)$ & $36.8 \mathrm{t}$ & 17 & $1.91^{a}$ & $57.1 \mathrm{~d}$ \\
\hline 3 & & $214.8 \mathrm{~s}$ & 18 & $1.69 \mathrm{~s}$ & $14.3 \mathrm{q}$ \\
\hline 4 & & $50.1 \mathrm{~s}$ & 19 & $1.29 \mathrm{brs}, 0.86 \mathrm{brs}$ & $28.3 \mathrm{t}$ \\
\hline 5 & $1.70^{a}$ & $44.1 \mathrm{~d}$ & 20 & $2.62 \mathrm{~m}$ & $24.5 \mathrm{~d}$ \\
\hline 6 & $1.70 \mathrm{~m}, 1.52 \mathrm{~m}$ & $21.9 \mathrm{t}$ & 21 & $1.47 \mathrm{~d}(6.6)$ & $22.5 \mathrm{q}$ \\
\hline 7 & 5.17 dd $(6.1,2.6)$ & $113.1 \mathrm{~d}$ & 22 & $2.10 \mathrm{~m}, 2.04 \mathrm{~m}$ & $40.7 \mathrm{t}$ \\
\hline 8 & & $149.1 \mathrm{~s}$ & 23 & & $106.6 \mathrm{~s}$ \\
\hline 9 & & $22.5 \mathrm{~s}$ & 24 & 4.45 brd (5.1) & $85.8 \mathrm{~d}$ \\
\hline 10 & & $27.7 \mathrm{~s}$ & 25 & & $77.8 \mathrm{~s}$ \\
\hline 11 & $2.82 \mathrm{dd}(15.1,8.9), 1.49 \mathrm{~m}$ & $39.8 \mathrm{t}$ & 26 & $4.32 \mathrm{~d}(8.7), 4.24 \mathrm{~d}(8.7)$ & $78.1 \mathrm{t}$ \\
\hline 12 & $4.23^{a}$ & $71.7 \mathrm{~d}$ & 27 & $1.91 \mathrm{~s}$ & $22.9 \mathrm{q}$ \\
\hline 13 & & $49.5 \mathrm{~s}$ & 28 & $1.12 \mathrm{~s}$ & $22.5 \mathrm{q}$ \\
\hline 14 & & $48.8 \mathrm{~s}$ & 29 & $1.01 \mathrm{~s}$ & $19.9 \mathrm{q}$ \\
\hline 15 & $2.14 \mathrm{~m}, 1.52 \mathrm{~m}$ & $43.8 \mathrm{t}$ & 30 & $1.04 \mathrm{~s}$ & $26.8 \mathrm{q}$ \\
\hline
\end{tabular}

${ }^{a}$ Signals overlapped. ${ }^{b}$ Recorded at $500 \mathrm{MHz}$ in pyridine- $d_{5} .{ }^{c}$ Recorded at $150 \mathrm{MHz}$ in pyridine- $d_{5}$. 
hydroxymethine at $\delta_{\mathrm{C}} 71.7(\mathrm{C}-12)$ and downfield shifted cyclopropane methylene $\left(\delta_{\mathrm{H}} 0.86\right.$ and 1.29) further supported the aforementioned deduction.

The spin system $-\mathrm{CH}_{2} \mathrm{CHCHCH}\left(\mathrm{CH}_{3}\right) \mathrm{CH}_{2}$ - due to C-15, C-16, $\mathrm{C}-17, \mathrm{C}-20$, Me-21 and C-22 was further deduced from ${ }^{1} \mathrm{H}-{ }^{1} \mathrm{H}$ COSY correlations (Fig. 1). In the HMBC spectrum, associations from M-18 $\left(\delta_{\mathrm{H}} 1.69\right)$ to $\mathrm{C}-13\left(\delta_{\mathrm{C}} 49.5\right)$ and $\mathrm{C}-17\left(\delta_{\mathrm{C}} 57.1\right)$, Me-28 $\left(\delta_{\mathrm{H}} 1.12\right)$ to $\mathrm{C}-13\left(\delta_{\mathrm{C}} 49.5\right), \mathrm{C}-14\left(\delta_{\mathrm{C}} 48.8\right)$, and C-15 $\left(\delta_{\mathrm{C}} 43.8\right)$, and $\mathrm{H}-15\left(\delta_{\mathrm{H}} 2.14\right.$ and 1.52$)$ to $\mathrm{C}-17\left(\delta_{\mathrm{C}} 57.1\right)$ established ring $\mathrm{D}$ as a cyclopentane ring. In addition, the linkages of the ketal carbon C-23 $\left(\delta_{\mathrm{C}} 106.6\right)$ to C-22 $\left(\delta_{\mathrm{C}} 40.7\right)$ and C-24 $\left(\delta_{\mathrm{C}} 85.5\right)$ were deduced from the HMBC correlations of the methylene $(\mathrm{H}-22)$ protons $\left(\delta_{\mathrm{H}} 2.10\right.$ and 2.04) and hydroxymethine ( $\left.\mathrm{H}-24\right)$ proton $\left(\delta_{\mathrm{H}} 4.45\right)$ to C-23, respectively. Similarly, the connections of C24, C-26 and Me-27 to C-25 were established by HMBC couplings of $\mathrm{H}-24$ at $\delta_{\mathrm{H}} 4.45$, geminal signals of the oxygenated methylene protons $(\mathrm{H}-26)$ at $\delta_{\mathrm{H}} 4.32$ and 4.24 (each $1 \mathrm{H}, \mathrm{d}, J=8.7$ $\mathrm{Hz}$ ), and $\mathrm{CH}_{3}-27$ at $\delta_{\mathrm{H}} 1.91$ to $\mathrm{C}-25\left(\delta_{\mathrm{C}} 77.8\right)$, respectively. Thus, to fulfill the unsaturation requirement, the molecular weight, and the chemical shift of C-16, C-23, C-25 and C-26, a 16,23:23,26-diepoxy moiety was established on the basis of rings $\mathrm{E}$ and $\mathrm{F}$ and the final hydroxy group was attached to C-25. Finally, the planar structure of $\mathbf{1}$ was constructed as shown.

The relative configuration of $\mathbf{1}$ was established by the ROESY spectrum (Fig. 1). The cross-peaks of $\mathrm{H}-12, \mathrm{H}-16$ and $\mathrm{H}-17$ with $\mathrm{CH}_{3}-28$ (biogenetically $\alpha$-oriented) in the ROESY spectrum assigned their orientations as $\alpha$. The $\alpha$-orientation of $\mathrm{CH}_{3}-21$ was deduced from ROESY correlation of $\mathrm{H}-20$ and $\mathrm{CH}_{3}-18$ (biogenetically $\beta$-oriented). In addition, $\mathrm{CH}_{3}-27\left(\delta_{\mathrm{H}} 1.91\right)$ showed correlations with $\mathrm{H}-24\left(\delta_{\mathrm{H}} 4.45\right)$ and $\mathrm{H}-26 \mathrm{~b}\left(\delta_{\mathrm{H}} 4.24\right)$, indicating same orientations of those protons and methyl in ring F. However, it was not possible to identify the absolute stereochemistry of C-23, C-24, and C-25 by ROESY experiment. Fortunately, 1 was crystallized from $\mathrm{MeOH}$ and analyzed by $\mathrm{X}$ ray crystallography, which allowed unambiguous assignment of the absolute configuration by a Flack parameter of 0.07(11). Accordingly, the absolute configurations at C-23, C-24 and C-25 were assigned as $R, R$, and $R$, respectively (Fig. 2). Therefore, the structure of $\mathbf{1}$, named yunnanterpene G, was determined as shown.

\subsection{Alteration of morphology and phenotype of PMA- induced THP-1 cells}

Normal THP-1 cells are round in shape and do not adhere to the plastic surfaces of culture plates. ${ }^{32}$ In the presence of $100 \mathrm{nM}$

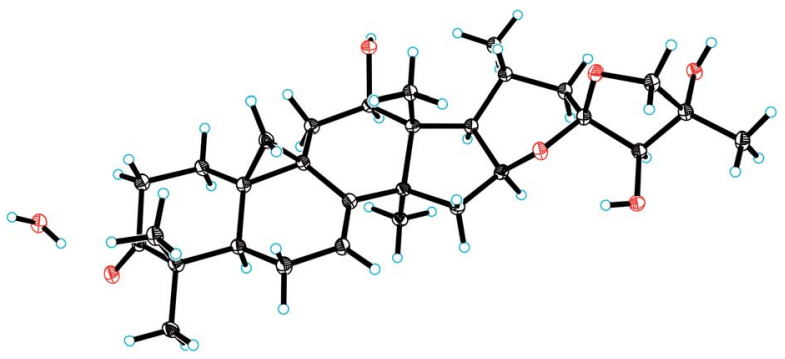

Fig. 2 X-ray crystal structure of 1.
PMA for $24 \mathrm{~h}$, the cells became flat and amoeboid in shape, and adhered to the dish bottom (Fig. S11A and S11B $\dagger$ ). Flow cytometry analysis revealed that $98 \%$ of the PMA-induced THP-1 cells were CD68 positive and $32 \%$ of these cells were CD11b positive, which confirmed the differentiation of monocyte to macrophage (Fig. S11C and S11D†).

\subsection{Effects of compound 1 on viability of PMA-induced THP- 1 cells}

The MTT assay was employed to evaluate the effect of 1 on the viability of PMA-induced macrophages. As shown in Fig. 3, compound 1 only caused weak reduction (about 10-15\%) in cell viability when the concentration was over $75 \mu \mathrm{M}$. Therefore, doses ranging from 10 to $50 \mu \mathrm{M}$ used in subsequent experiments were considered to be non-cytotoxic.

\subsection{The effect of compound 1 on expression of CD147 and MMP MRNA of PMA-induced THP-1 cells}

CD147 and MMP mRNA levels in PMA-differentiated THP-1 cells were tested by q-PCR using the $2^{-\Delta \Delta C_{\mathrm{t}}}$ method. As shown in Fig. 4A, the expression of CD147 was significantly higher in PMA-induced THP-1 cells than the NC group $(p<0.001)$. After 24 hours treatment with 1 on the differentiated THP-1 cells, CD147 mRNA expression was notably downregulated in the 10, 25, and $50 \mu \mathrm{M}$ treatment groups $(p<0.05, p<0.001$, and $p<0.001$, respectively; Fig. 4A). Since CD147 could stimulate production of MMP-2, MMP-9, and MMP-14 in the activated macrophages, ${ }^{\mathbf{1 1 - 1 4}}$ the effects of compound 1 on mRNA expressions of these metalloproteinases were further studied. As shown in Fig. 4B-D, the levels of MMP-2, MMP-9, and MMP-14 mRNA were markedly and dose-dependently suppressed by $\mathbf{1}$.

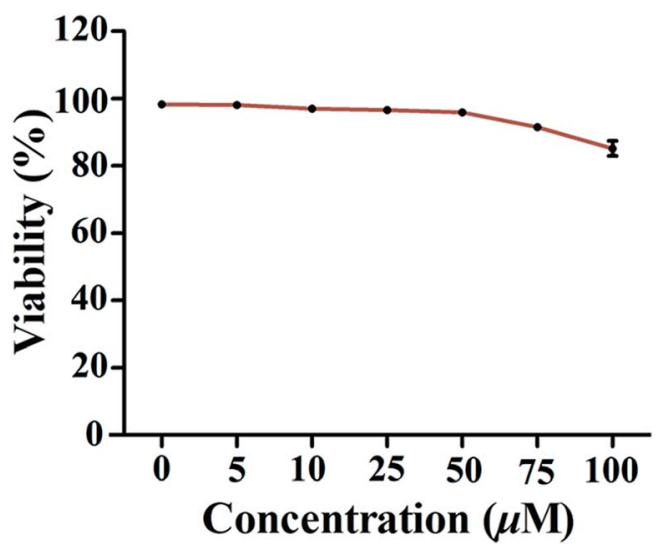

Fig. 3 Effect of yunnanterpene $G$ on the viability of PMA-induced THP-1 cells. PMA-induced THP-1 cells were treated with indicated concentrations of yunnanterpene $\mathrm{G}(10-100 \mu \mathrm{M})$ and cell viability was assessed after $48 \mathrm{~h}$ using the MTT assay. Cells incubated in a medium without yunnanterpene $G$ were defined as control. Data points represent mean $\pm \mathrm{SD}$ of three measurements. 

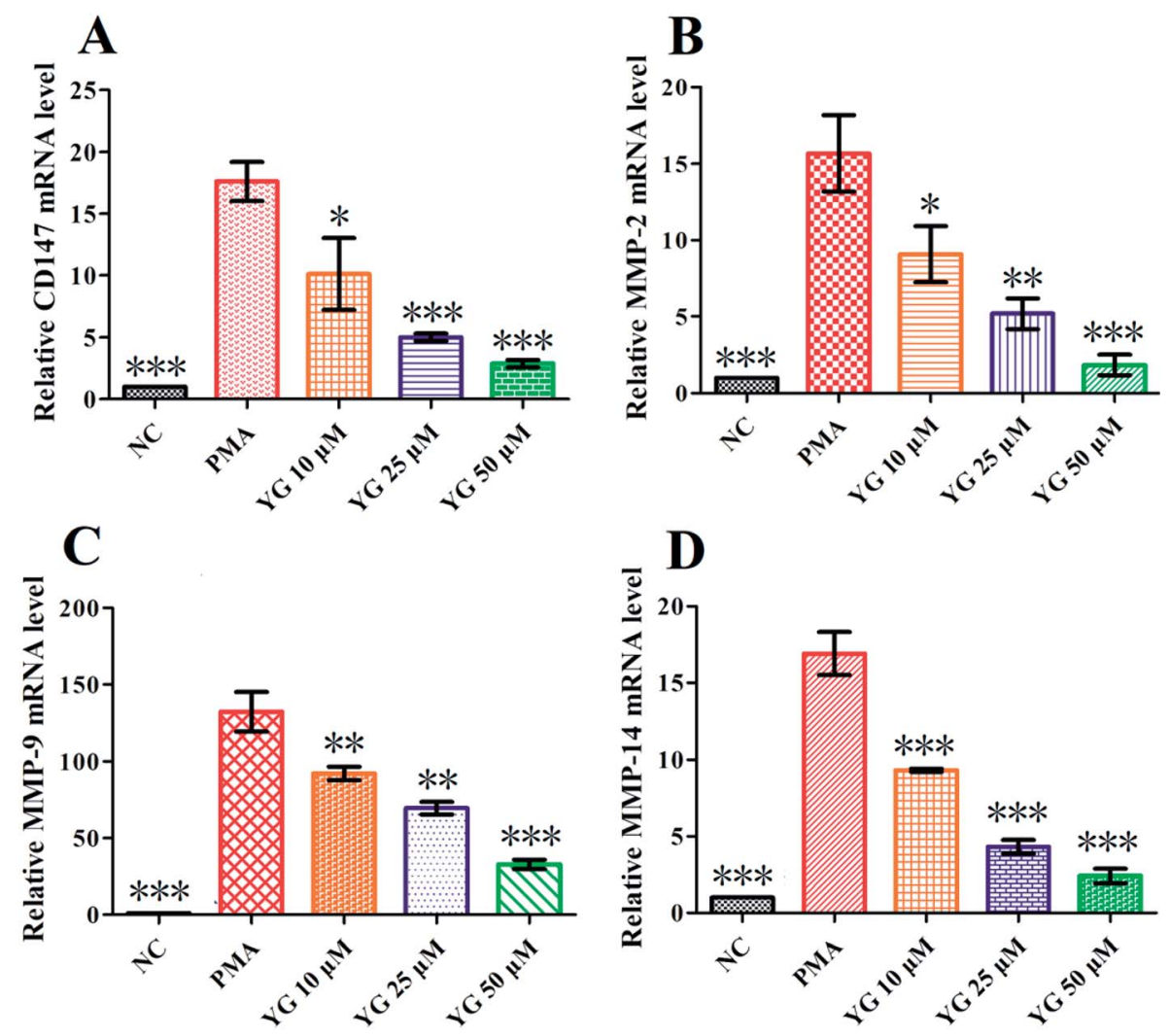

Fig. 4 Yunnanterpene G suppressed mRNA expression of CD147, MMP-2, MMP-9 and MMP-14. (A) Suppression of yunnanterpene G on CD147 mRNA. (B) Suppression of yunnanterpene G on MMP-2 mRNA. (C) Suppression of yunnanterpene G on MMP-9 mRNA. (D) Suppression of yunnanterpene $G$ on MMP-14 mRNA. Relative quantification of gene expression was performed by the $2^{-\Delta \Delta C_{t}}$ method. The results show the means \pm SD from three independent experiments. Significant difference was compared with PMA group: $(*) p<0.05,(* *) p<0.01,(* * *) p<0.001$. NC: negative control (undifferentiated THP-1 cells); PMA: PMA-differentiated THP-1 cells; YG $10 \mu M$ : PMA-differentiated THP-1 cells were treated with $10 \mu$ M yunnanterpene G for 24 h; YG $25 \mu$ M: PMA-differentiated THP-1 cells were treated with $25 \mu M$ yunnanterpene G for 24 h; YG $50 \mu \mathrm{M}$ : PMA-differentiated THP-1 cells were treated with $50 \mu \mathrm{M}$ yunnanterpene $\mathrm{G}$ for $24 \mathrm{~h}$. Expression of mRNA is defined as the change in mRNA copy numbers relative to NC group.

\subsection{The effect of compound 1 on the migration of PMA- induced THP-1 cells}

In the pathological process of atherosclerosis, the enhanced migration or invasion of peripheral macrophages is always observed..$^{13,14}$ Thus, the effect of compound 1 on the migration of PMA-induced THP-1 cells was evaluated by scratch wound assay. Compound $\mathbf{1}$ (after $24 \mathrm{~h}$ incubation) reduced the motility of PMA-induced THP-1 cells in a dose-dependent manner. Fig. 5 shows that the number of migrated cells was significantly fewer than those of vehicle-treated wells in the 10,25 , and $50 \mu \mathrm{M}$ treatment groups $(p<0.01, p<0.001$, and $p<0.001)$.

\subsection{The NF-кB and MAPK pathways were involved in the inhibitory effect of compound 1 on CD147 and MMP mRNA expression in PMA-induced THP-1 cells}

In atherosclerosis, CD147 is involved in a variety of signaling pathways, including NF- $\kappa \mathrm{B}, \mathrm{MAPK}$, and JAK/STAT, to regulate pathological processes in different ways. ${ }^{33-36}$ Therefore, it was of interest to examine whether these pathways were also affected by compound 1 in PMA-induced macrophages. In the present study, after differentiated THP-1 cells had been treated with 1

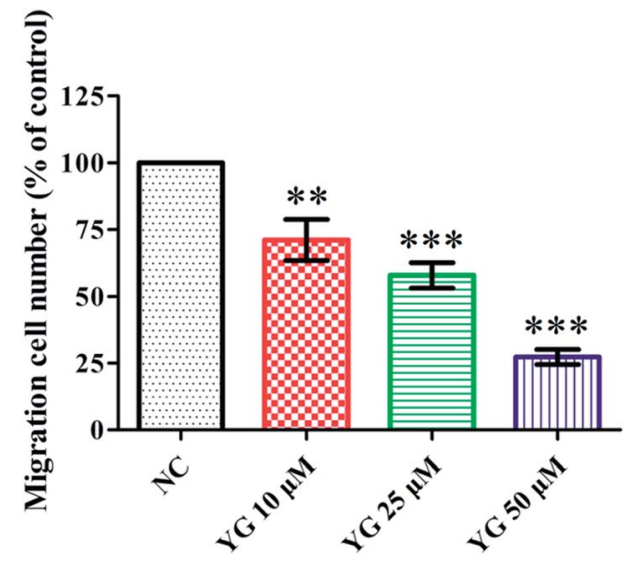

Fig. 5 The inhibition of yunnanterpene $G$ on the migration of PMAinduced THP-1 cells. Cells were wounded with a pipette then treated with 0 (NC), 10 (YG $10 \mu \mathrm{M}), 25$ (YG $25 \mu \mathrm{M})$, and 50 (YG $50 \mu \mathrm{M}) \mu \mathrm{M}$ yunnanterpene $G$. After $24 \mathrm{~h}$, the migrated cells were quantified by Image Pro Plus software. The migration cell number of PMA-induced THP-1 cell group was defined as NC and set to $100 \%$. The results show the means \pm SD from three independent experiments. Significant difference was compared with NC group: $\left(^{*}\right) p<0.05,\left(^{* *}\right) p<0.01$, $(* * *) p<0.001$. 

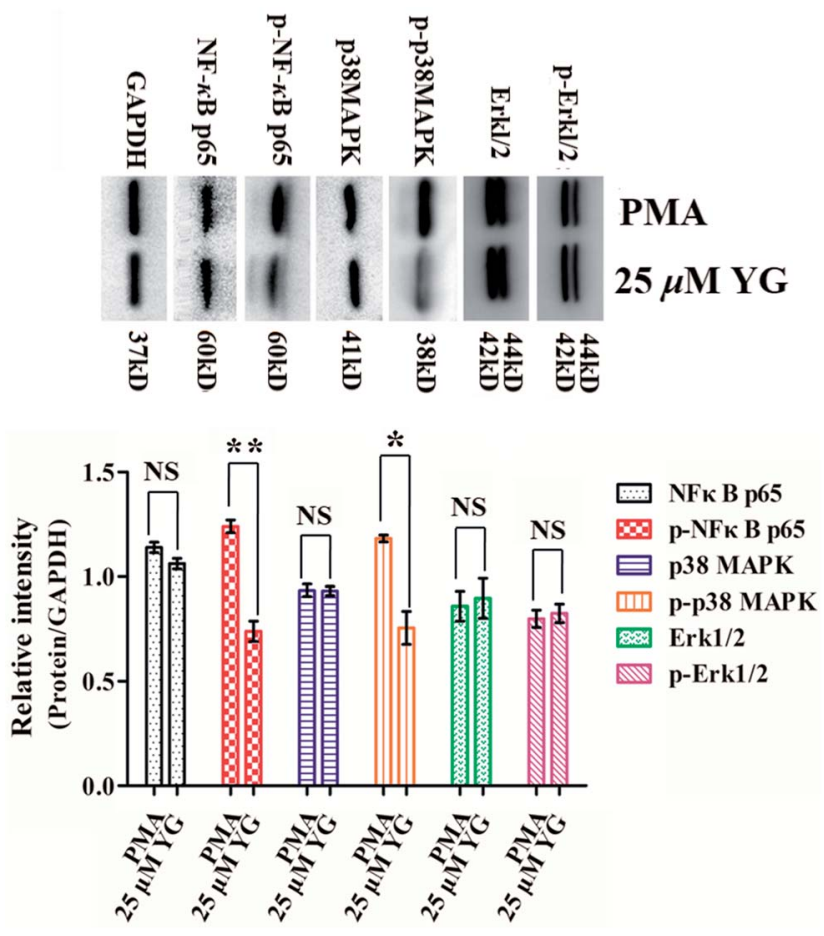

Fig. 6 Yunnanterpene $G$ suppressed the phosphorylation of NF- $\mathrm{B} B$ p65 and p38 MAPK in PMA-induced THP-1 cells. Cells were treated with (25 $\mu$ M YG group) or without (PMA group) yunnanterpene $G$ at a concentration of $25 \mu \mathrm{M}$ for $4 \mathrm{~h}$. The cell lysates were collected for western blotting. The GAPDH expression was used for protein level normalization. The results show the means $\pm S D$ from three independent experiments. Significant difference was compared with each PMA group: $(*) p<0.05,(* *) p<0.01$

$(25 \mu \mathrm{M})$ for $4 \mathrm{~h}$, the phosphorylations of NF- $\kappa \mathrm{B}$ p65 and p38 MAPK were significantly inhibited $(p<0.05$ and $p<0.01$, respectively; Fig. 6). Therefore, these data suggest that NF- $\kappa$ B and p38 MAPK signaling pathways are involved in the regulation of the effect of 1 on EMMPRIN and MMP expression in PMA-induced THP-1 cells.

The stability of atherosclerotic plaques is the key point of the transformation for stable angina pectoris or a life-threatening acute coronary syndrome, including acute myocardial infarction and unstable angina pectoris..$^{\mathbf{1 3 1 4 , 3 7}}$ In that process, MMPs, from macrophages and macrophage-derived foam cells of arterial wall, are responsible for extracellular matrix degradation and remodeling, which ultimately weaken the atherosclerotic lesion and promote plaque rupture in the arterial wall. ${ }^{\mathbf{1 1 - 1 4}}$ CD147, an adhesion molecule, is an upstream regulator of MMPs in atherosclerotic plaque. ${ }^{7-10}$ Importantly, the clinical outcomes of statins have been shown to attribute to both their LDL reducing and CD147 and MMP lowering effects. ${ }^{15-17}$ In addition, CD147-blocking antibodies, antagonistic peptides, and siRNA have been used in animal models to reduce tissue inflammation. ${ }^{38} \mathrm{CD}_{147^{+/-}}$mice and mAb anti-CD147-treated WT-mice are largely protected from myocardial I/R injury. ${ }^{39}$ Thus, preventing the rupture of atherosclerotic plaques by inhibition of CD147 and MMPs may have benefit in atherosclerosis therapy.
Although prominent biological activities of CTs from Cimicifuga spp. have been reported, to date, however, knowledge of the inhibition of those chemical constituents on CD147 and MMPs is mainly not yet clear. For the first time, yunnanterpene G, a CT from C. foetida, showed notable suppression of mRNA expression of CD147, MMP-2, MMP-9 and MMP-14 in PMAinduced THP-1 cells. Moreover, the migration of differentiated THP-1 cells was also inhibited by yunnanterpene G. Finally, a preliminary mechanistic study suggested that the aforementioned bioactivities of yunnanterpene $G$ were related to its inhibition on NF- $\kappa$ B and p38 MAPK pathways. Yunnanterpene G represents a new type of active structural prototype, and, given the important roles of CD147 and MMP expression in the development of atherosclerosis, this compound and its modified analogues deserve further studies for their health-related properties in stabilizing atherosclerotic plaque, and thus ameliorating the development of atherosclerosis in future.

\section{Conclusions}

In summary, yunnanterpene G (1), a new spiro-triterpene from the roots of $C$. foetida, downregulates expression of CD147 and MMPs in PMA-induced THP-1 cells through suppressing NF- $\kappa \mathrm{B}$ and p38 MAPK signaling pathways' activation. Since suppression of CD147 and MMPs could stabilize atherosclerotic plaque, these results highlight a promising role of yunnanterpene $\mathrm{G}$ in retarding the development of the vulnerability of such plaque. More sophisticated animal studies are needed to clarify yunnanterpene G's in vivo anti-atherosclerosis effect.

\section{Experimental section}

\subsection{General experimental procedures}

Column chromatography (CC) was run on silica gel (200-300 mesh, Qingdao Marine Chemical, Inc.) and Lichroprep RP-18 (40-63 $\mu \mathrm{m}$, Merck). Semipreparative HPLC was carried out on an Agilent 1100 liquid chromatography system using a YMCPack $10 \mathrm{~mm} \times 250 \mathrm{~mm}$ column (Pro C18 RS). Precoated TLC plates (200-250 $\mu \mathrm{m}$ thickness, silica gel $60 \mathrm{~F}_{254}$, Qingdao Marine Chemical, Inc.) were used for thin-layer chromatography. 1D and 2D NMR spectra were obtained using Bruker DRX-500 and Avance III-600 MHz spectrometers (Bruker, Zürich, Switzerland) with solvent signal as internal reference. ESIMS and HRESIMS were run with a Shimadzu LCMS-IT-TOF mass spectrometer (Shimadzu, Kyoto, Japan) or an Agilent G6230 TOF MS (Agilent Technologies, Palo Alto, USA). Infrared spectra were obtained using a Shimadzu IR-450 instrument with KBr pellets. A JASCO $\mathrm{P}-1020$ digital polarimeter was applied to record optical rotations, using $\mathrm{MeOH}$ as solvent. X-ray diffraction was realized with a Bruker SMART APEX CCD crystallography system. Flow cytometry analysis was conducted with a PARTEC brand flow cytometer (Germany). Quantitative PCR (q-PCR) was conducted with a ProFlex ${ }^{\mathrm{TM}}$ PCR system (Thermo Fisher, Shanghai, China). SDS-PAGE was carried out with a Mini-Protean Tetra Electrophoresis System (Bio-Rad, Shanghai, China). 


\subsection{Materials}

4.2.1. Plant materials. The roots of Cimicifuga foetida $(3.0$ $\mathrm{kg}$ ) were purchased from Luoshiwan Chinese herbal medicine market, Kunming, Yunnan, China, in September 2016. A voucher specimen (no. 20160923) has been deposited at Department of Cardiology, Kunming General Hospital of Chengdu Military Area, Yunnan, 650032, PR China.

4.2.2. Reagents. Human monocytic THP-1 cells were purchased from Kunming Cell Bank, Kunming Institute of Zoology, Chinese Academy of Sciences. All reagents used for cell culture including penicillin/streptomycin, FBS (fetal bovine serum) and DMEM/F12 medium were purchased from Thermo Fisher (Shanghai China). PMA was purchased from Sigma Chemical Co. (St Louis, MO). Restriction enzymes and Taq polymerase were obtained from Takara, and FITC-labeled antihuman CD68 and CD11b antibodies were purchased from Thermo Fisher (Shanghai China). RevertAid ${ }^{\mathrm{TM}}$ First Strand cDNA Synthesis Kit was from Thermo Fisher (Shanghai China). PrimeScript RT reagent kit was obtained from Takara Bio (Japan).

\subsection{Extraction and isolation}

MeOH (10 L, 3 times, 7 days each) was used to extract the dried and milled fruits of Cimicifuga foetida $(3.0 \mathrm{~kg})$ at room temperature. $\mathrm{MeOH}$ was evaporated under vacuum at $50{ }^{\circ} \mathrm{C}$ to afford the extract $(406.8 \mathrm{~g})$. The extract was divided to fractions A (46.7 g), B (78.2 g), C (67.5 g), D (58.1 g) and E (40.5 g) by silica gel CC $(5.0 \mathrm{~kg}, 20 \times 200 \mathrm{~cm})$ eluted with $\mathrm{CHCl}_{3}-\mathrm{MeOH}[100: 0$ $(10 \mathrm{~L}), 50: 1(20 \mathrm{~L}), 10: 1(20 \mathrm{~L}), 5: 1$ (15 L), $0: 100(7 \mathrm{~L})]$. Subsequently, five sub-fractions (B.1-B.7) were obtained through further silica $\mathrm{CC}(3 \mathrm{~kg}, 10 \times 150 \mathrm{~cm})$, eluting with $\mathrm{CHCl}_{3}-\mathrm{Me}_{2} \mathrm{CO}$ from $40: 1$ gradient to $5: 1$. Fractions (B.5.1B.5.5) were obtained by RP-18 CC (eluted with $\mathrm{MeOH}-\mathrm{H}_{2} \mathrm{O}$, gradient from $50: 50$ to $100: 0$ ) of fraction B.5. Compound 1 $(6.5 \mathrm{mg})$ was purified from fraction B.5.3 $(6.7 \mathrm{~g})$ by silica gel CC $\left(80 \mathrm{~g}, 5 \times 40 \mathrm{~cm}\right.$ ) eluted with $\mathrm{CHCl}_{3}-\mathrm{Me}_{2} \mathrm{CO}$ (gradient from $20: 1$ to $5: 1$ ), and then repeated semipreparative HPLC (eluted with $\mathrm{CH}_{3} \mathrm{CN}-\mathrm{H}_{2} \mathrm{O}$, gradient from $50: 50$ to $\left.75: 25\right)$.

4.3.1 $(12 \beta, 23 R, 24 R, 25 R)-16,23: 23,26-D i e p o x y-12,24,25-$

trihydroxy-9,19-cycloart-7-en-3-one (1). Colorless crystals; mp 198-200 ${ }^{\circ} \mathrm{C} ;[\alpha]_{\mathrm{D}}^{20}-39.0$ (c 0.11, MeOH); IR (KBr) $\nu_{\max } 3411$, 2931, 2855, 1705, 1631, 1453, 1383, 1180, 1111, $1026 \mathrm{~cm}^{-1} ;{ }^{1} \mathrm{H}$ NMR $\left(\mathrm{C}_{5} \mathrm{D}_{5} \mathrm{~N}, 500 \mathrm{MHz}\right)$ and ${ }^{13} \mathrm{C}$ NMR $\left(\mathrm{C}_{5} \mathrm{D}_{5} \mathrm{~N}, 150 \mathrm{MHz}\right)$ spectra, see Table 1; ESIMS: $m / z 523[\mathrm{M}+\mathrm{Na}]^{+}$; HRESIMS: $m / z$ 523.3029 (calc. for $\mathrm{C}_{30} \mathrm{H}_{44} \mathrm{O}_{6}, 523.3036$ ).

\subsection{X-ray crystal structure analysis}

Colorless crystals of 1 were obtained from $\mathrm{CH}_{3} \mathrm{OH}$. Intensity data were collected at $100 \mathrm{~K}$ using a Bruker APEX DUO diffractometer equipped with an APEX II CCD, using $\mathrm{Cu} \mathrm{K} \alpha$ radiation. Cell refinement and data reduction were performed with Bruker SAINT. The structures were solved by direct methods using SHELXS-97. ${ }^{22}$ Refinements were performed with SHELXL-97, using full-matrix least-squares, with anisotropic displacement parameters for all the non-hydrogen atoms. The $\mathrm{H}$ atoms were placed in calculated positions and refined using a riding model. Molecular graphics were computed with PLATON. Crystallographic data (excluding structure factor tables) for the structures reported have been deposited with the Cambridge Crystallographic Data Centre as supplementary publication no. CCDC 1813083.

Yunnanterpene $\mathrm{G}(1): \mathrm{C}_{30} \mathrm{H}_{44} \mathrm{O}_{6} \cdot \mathrm{H}_{2} \mathrm{O}, M=518.67, a=$ 6.1629(2) А, $b=18.1237(6) \AA, c=12.4853(4) \AA, \alpha=90^{\circ}, \beta=$ 102.545(2) $)^{\circ}, \gamma=90^{\circ}, V=1361.25(8) \AA^{3}, T=100(2) \mathrm{K}$, space group $P 2_{1}, Z=2, \mu(\mathrm{CuK} \alpha)=0.713 \mathrm{~mm}^{-1}, 11631$ reflections measured, 4459 independent reflections $\left(R_{\text {int }}=0.0451\right)$. The final $R_{1}$ values were $0.0456(I>2 \sigma(I))$. The final $w R\left(F^{2}\right)$ values were $0.1194(I>2 \sigma(I))$. The final $R_{1}$ values were 0.0472 (all data). The final $w R\left(F^{2}\right)$ values were 0.1209 (all data). The goodness of fit on $F^{2}$ was 1.047. Flack parameter $=0.07(11)$. The Hooft parameter is $0.08(11)$ for 1885 Bijvoet pairs.

\subsection{Cell culture and differentiation}

Human monocytic THP-1 cells were cultured in DMEM/F12 medium supplemented with $10 \%$ fetal bovine serum and $1 \%$ penicillin/streptomycin at $37^{\circ} \mathrm{C}$ in a humidified atmosphere of $5 \% \mathrm{CO}_{2}$. For the induction of cell differentiation, cells $\left(5 \times 10^{5}\right.$ to $10^{6}$ per $\mathrm{ml}$ ) were seeded in DMEM/F12 serum medium with $100 \mathrm{nM}$ PMA for $24 \mathrm{~h}$. After incubation, nonattached cells were removed by aspiration, and the adherent cells were washed with DMEM/F12.

\subsection{Flow cytometry analysis}

Expression of CD68 and CD11b on the surface of the differentiated THP-1 cells was determined by flow cytometry. Cells $(5 \times$ $10^{5}$ ) were washed 3 times with phosphate-buffered saline (PBS) and then were treated successively with fluorescein isothiocyanate (FITC)-conjugated anti-CD68 antibody, and FITCconjugated anti-CD11b antibody, for 20 minutes in a dark condition. Cells were washed with PBS and then analyzed with a PARTEC CyFlow ${ }^{\circledR}$ Cube flow cytometer. Data were processed using the CytExpert software.

\subsection{MTT assay}

The differentiated THP-1 cells were suspended in DMEM/F12 medium with $10 \%$ FBS, plated onto gelatinized 96-well culture plates $\left(5 \times 10^{5}\right.$ cells per $\mathrm{ml}, 0.1 \mathrm{ml}$ per well), and incubated at $37{ }^{\circ} \mathrm{C}$ with $5 \% \mathrm{CO}_{2}$ for $24 \mathrm{~h}$. Then, the medium was replaced with $0.1 \mathrm{ml}$ of DMEM/F12, containing different concentrations of yunnanterpene $\mathrm{G}(0,5,10,25,50,75$, and $100 \mu \mathrm{M})$, and incubated for $48 \mathrm{~h}$ at $37{ }^{\circ} \mathrm{C}$ with $5 \% \mathrm{CO}_{2}$. Cell viability was determined by MTT assay. In the MTT assay, $20 \mu \mathrm{l}$ of MTT was added to each well (final MTT concentration was $0.5 \mathrm{~g} \mathrm{~L}^{-1}$ ) for $4 \mathrm{~h}$ before the addition of $150 \mu \mathrm{l}$ DMSO to solubilize the reactive dye. The absorbance value of each well was recorded at $570 \mathrm{~nm}$ using a Bio-Rad microplate reader. All the experiments were performed in triplicate. 


\subsection{Isolation of total RNA and RT-PCR}

Total RNA was extracted from differentiated THP-1 cells treated with yunnanterpene $\mathrm{G}(10,25$, and $50 \mu \mathrm{M})$ for $24 \mathrm{~h}\left(5 \times 10^{5}\right.$ cells per $\mathrm{ml}$ ) using RevertAid ${ }^{\mathrm{TM}}$ First Strand cDNA Synthesis Kit according to the manufacturer's instructions. Synthesis of cDNA from the isolated total RNA was conducted using the PrimeScript RT reagent kit. In brief, $5 \times$ PrimeScript $^{\mathrm{TM}}$ Buffer $(2$ $\mu \mathrm{l})$, PrimeScript RT Enzyme Mix $1(0.5 \mu \mathrm{l})$, oligo dt Primer $(0.5$ $\mu \mathrm{l})$ and Random 6 mers $(0.5 \mu \mathrm{l})$ were added to $1 \mu \mathrm{g}$ RNA from each sample. The reaction volume was brought to $10 \mu \mathrm{l}$ with RNase-free water, mixed gently, and incubated at $37{ }^{\circ} \mathrm{C}$ for 15 minutes to activate the reverse transcriptase enzyme and $85{ }^{\circ} \mathrm{C}$ for 5 seconds to inactivate the reaction.

After reverse transcription, cDNA was used for real-time quantitative RT-PCR with a ProFlex ${ }^{\mathrm{TM}}$ PCR system using SYBR Premix Ex Taq (Takara). The RT-PCR was performed in a final volume of $25 \mu \mathrm{l}$ containing $12.5 \mu \mathrm{l}$ SYBR green master mix, $1 \mu \mathrm{l}$ cDNA, $0.5 \mu \mathrm{l}$ each forward and reverse primer, and $10.5 \mu \mathrm{l}$ nuclease-free water. Primer information is in Table S1. $\dagger$ Thermal cycling conditions for all genes were as follows: template pre-denaturation $\left(10 \mathrm{~min}\right.$ at $\left.95{ }^{\circ} \mathrm{C}\right)$, denaturation $(15$ seconds at $\left.95{ }^{\circ} \mathrm{C}\right)$, annealing and extension $\left(30\right.$ seconds at $60^{\circ} \mathrm{C}$ ) for 40 cycles. Experiments were performed in triplicate for each data point. GAPDH mRNA was amplified as a housekeeping gene, and fold changes in each target mRNA expression relative to $G A P D H$ were calculated by the $2^{-\Delta \Delta C_{\mathrm{t}}}$ method. Expression of mRNA is defined as the change in mRNA copy numbers relative to negative control cells (undifferentiated THP-1 cells). All the experiments were performed in triplicate.

\subsection{Wound-healing migration assay}

The differentiated THP-1 cells were seeded and grown into full confluence in 6-well plates. Cells were starved with $2 \%$ FBS DMEM/F12 media for $12 \mathrm{~h}$ to inactivate cell proliferation and then wounded by pipette tips. Fresh DMEM/F12 medium with or without 10,25 , and $50 \mu \mathrm{M}$ yunnanterpene $\mathrm{G}$ was added to the scratched monolayers. Images were taken after 24 hours using an inverted microscope (magnification, 10×; Nikon). The migration cell number of PMA-induced THP-1 cell group was defined as control. All the experiments were performed in triplicate.

\subsection{Western blot assay}

The differentiated THP-1 cells were serum-starved overnight, then pretreated with $25 \mu \mathrm{M}$ yunnanterpene $\mathrm{G}$ for $4 \mathrm{~h}$. Cells were lysed with buffer containing $50 \mathrm{mM}$ Tris, $150 \mathrm{mM} \mathrm{NaCl}, 1 \mathrm{mM}$ EDTA, 1\% Triton X-100, 1\% sodium deoxycholate, 0.1\% SDS, $2 \mathrm{mM}$ sodium pyrophosphate, $25 \mathrm{mM} \beta$-glycerophosphate, $40 \mathrm{mmol} \mathrm{L}^{-1} \mathrm{NaF}, 10 \mathrm{mmol} \mathrm{L}^{-1} \mathrm{Na}_{4} \mathrm{P}_{2} \mathrm{O}_{7}$, proteinase inhibitor cocktail and $1 \mathrm{mmol} \mathrm{L}^{-1}$ phenylmethylsulfonyl fluoride. Protein concentrations were determined by Bradford assay and equalized before loading. About $80 \mu \mathrm{g}$ cellular proteins were separated using gradient SDS-PAGE gels and probed with specific antibodies (abcam) including NF- $\kappa \mathrm{B}$ p65, phospho-NF- $\kappa \mathrm{B}$ (phospho S536) p65, p38 MAPK, phospho-p38 MAPK (phospho
T180/Y182), Erk1/2, phosphor-Erk1/2 (phospho Thr202/Tyr204), HRP, and GAPDH. Blots were visualized with enhanced chemiluminescence reagent.

\subsection{Statistical analysis}

Data were presented as mean \pm SD. Statistical analysis of data was performed with Student's $t$-test for unpaired data in two trails. (*) $p<0.05$, (**) $p<0.01$, and (***) $p<0.001$ were considered significant.

\section{Conflicts of interest}

There are no conflicts of interest to declare.

\section{Acknowledgements}

We greatly acknowledge the help from Doctor Haiyuan Li for the experiment design and language polishing.

\section{Notes and references}

1 C. P. Wang, R. Jin, X. L. Zhu, J. C. Yan and G. H. Li, J. Cardiovasc. Transl. Res., 2015, 8, 59-66.

2 R. Ross, N. Engl. J. Med., 1999, 340, 115-126.

3 R. P. Choudhury and J. M. Lee, Nat. Clin. Pract. Cardiovasc. Med., 2005, 2, 309-315.

4 K. T. Iacono, A. L. Brown, M. I. Greene and S. J. Saouaf, Exp. Mol. Pathol., 2007, 83, 283-295.

5 E. E. Gabison, T. Hoang-Xuan, A. Mauviel and S. Menashi, Biochimie, 2005, 87, 361-368.

6 K. D. Curtin, I. A. Meinertzhagen and R. J. Wyman, J. Cell Sci., 2005, 118, 2649-2660.

7 Y. W. Yoon, H. M. Kwon, K. C. Hwang, E. Y. Choi, B. K. Hong, D. Kim, H. S. Kim, S. H. Cho, K. S. Song and G. Sangiorgid, Atherosclerosis, 2005, 180, 37-44.

8 D. A. Siwik, G. M. Kuster, J. V. Brahmbhatt, Z. Zaidi, J. Malik, H. Ooi and G. Ghorayeb, J. Mol. Cell. Cardiol., 2008, 44, 210217.

9 F. G. Spinale, M. L. Coker, L. J. Heung, B. R. Bond, H. R. Gunasinghe, T. Etoh, A. T. Goldberg, J. L. Zellner and A. J. Crumbley, Circulation, 2000, 102, 1944-1949.

10 E. Y. Choi, D. Kim, B. K. Hong, H. M. Kwon, Y. G. Song, K. H. Byun, K. C. Whang and H. S. Kim, Exp. Mol. Med., 2002, 34, 391-400.

11 R. Li, L. Huang, H. Guo and B. P. Toole, J. Cell. Physiol., 2001, 186, 371-379.

12 T. C. Major, L. Liang, X. Lu, W. Rosebury and T. M. Bocan, Arterioscler., Thromb., Vasc. Biol., 2002, 22, 1200-1207.

13 R. Schmidt, A. Bultmann, M. Ungerer, N. Joghetaei, O. Bülbül, S. Thieme, T. Chavakis, B. P. Toole, M. Gawaz, A. Schömig and A. E. May, Circulation, 2006, 113, 834-841.

14 D. L. Brown, M. S. Hibbs, M. Kearney, C. Loushin and J. M. Isner, Circulation, 1995, 91, 2125-2131.

15 N. Abe, T. Osanai, T. Fujiwara, K. Kameda, T. Matsunaga and K. Okumura, Life Sci., 2006, 78, 1021-1028. 
16 S. Bellosta, D. Via, M. Canavesi, P. Pfister, R. Fumagalli, R. Paoletti and F. Bernini, Arterioscler., Thromb., Vasc. Biol., 1998, 18, 1671-1678.

17 N. Ferri, G. Colombo, C. Ferrandi, E. W. Raines, B. Levkau and A. Corsini, Arterioscler., Thromb., Vasc. Biol., 2007, 27, 1043-1049.

18 J. X. Li and Z. Y. Yu, Curr. Med. Chem., 2006, 13, 2927-2951.

19 Y. Q. Guo, T. Yin, X. M. Wang, F. Zhang, G. X. Pan, H. Lv, X. R. Wang, J. O. Orgah, Y. Zhu and H. H. Wu, J. Ethnopharmacol., 2017, 209, 264-282.

20 A. Imai, D. C. Lankin, D. Nikolić, S. Ahn, R. B. Breemen, N. R. Farnsworth, J. B. McAlpine, S. N. Chen and G. F. Pauli, J. Nat. Prod., 2016, 79, 541-554.

21 Y. Nian, H. Zhu, W. R. Tang, Y. Luo, J. Du and M. H. Qiu, J. Nat. Prod., 2013, 76, 896-902.

22 Y. Nian, H. Yan, X. N. Li, L. Zhou and M. H. Qiu, RSC Adv., 2017, 7, 38557-38564.

23 Y. Nian, J. Yang, T. Y. Liu, Y. Luo, J. H. Zhang and M. H. Qiu, Sci. Rep., 2015, 5, 9026-9031.

24 Y. Su, L. Wu, Q. H. Wang, B. Y. Yang and H. X. Kuang, Bioorg. Med. Chem. Lett., 2014, 24, 5688-5691.

25 Y. Su, L. Wu, G. R. Mu, Q. H. Wang, B. Y. Yang, G. H. Cheng and H. X. Huang, Bioorg. Med. Chem., 2017, 25, 4917-4923.

26 C. N. Lv, F. Yang, R. L. Qin, Z. Y. Qi, W. R. Zhou and J. C. Lu, Bioorg. Med. Chem. Lett., 2017, 27, 3305-3309.

27 N. P. Thao, B. T. T. Luyen, J. S. Lee, J. H. Kim, N. T. Dat and Y. H. Kim, J. Nat. Prod., 2017, 80, 1867-1875.

28 J. X. Li, J. Liu, C. C. He, Z. Y. Yu, Y. S. Kadota and H. Seto, Maturitas, 2007, 58, 59-69.
29 N. Sakurai, J. H. Wu, Y. Sashida, Y. Mimaki, T. Nikaido, K. Koike, H. Itokawa and K. H. Lee, Bioorg. Med. Chem. Lett., 2004, 14, 1329-1332.

30 M. A. Findeis, F. Schroeder, T. D. McKee, D. Yager, P. C. Fraering, S. P. Creaser, W. F. Austin, J. Clardy, R. Wang, D. Selkoe and C. B. Eckman, ACS Chem. Neurosci., 2012, 3, 941-951.

31 J. Auwerx, Experientia, 1991, 47, 22-31.

32 J. Zhou, P. Zhu, J. L. Jiang, Q. Zhang, Z. B. Wu, X. Y. Yao, H. Tang, N. Lu, Y. Yang and Z. N. Chen, BMC Cell Biol., 2005, 6, 25-34.

33 W. Yuan, H. Ge and B. He, Atherosclerosis, 2010, 213, 415421.

34 A. J. Muslin, Clin. Sci., 2008, 115, 203-218.

35 H. Motoshima, B. J. Goldstein, M. Igata and E. Araki, J. Physiol., 2006, 574, 63-71.

36 G. Ortiz-Muñoz, J. L. Martin-Ventura, P. Hernandez-Vargas, B. Mallavia, V. Lopez-Parra, O. Lopez-Franco, B. MuñozGarcia, P. Fernandez-Vizarra, L. Ortega, J. Egido and C. Gomez-Guerrero, Arterioscler., Thromb., Vasc. Biol., 2009, 29, 525-531.

37 Y. Wang, Z. Q. Huang, C. Q. Wang, L. S. Wang, S. Meng, Y. C. Zhang, T. Chen and Y. Q. Fan, Clin. Exp. Pharmacol. Physiol., 2011, 38, 11-18.

38 P. Zhu, N. Lu, Z. G. Shi, J. Zhou, Z. B. Wu, Y. Yang, J. Ding and Z. N. Chen, Arthritis Res. Ther., 2006, 8, R44.

39 P. Seizer, C. Ochmann, T. Schönberger, S. Zach, M. Rose, O. Borst, K. Klingel, R. Kandolf, H. R. MacDonald, R. A. Nowak, S. Engelhardt, F. Lang, M. Gawaz and A. E. May, Arterioscler., Thromb., Vasc. Biol., 2011, 31, 13771386. 